\title{
THE PRESENCE AND DEPICTION OF WOMEN ON THE FRONT PAGES OF CROATIAN DAILY NEWSPAPERS: IN THE SERVICE OF PROMOTING GENDER STEREOTYPES?
}

\section{Dunja Majstorović :: Gordana Vilović}

IZVORNI ZNANSTVENI RAD / DOI: 10.20901/ms.8.16.2 / PRIMLJENO: 28.03.2017.

\begin{abstract}
In accordance with its traditional role of creating and cultivating public opinion, one should not neglect the fact that the media also serves as a tool in promoting or eradicating prejudices and stereotypes. In terms of the representation of women (their presence and the way they are portrayed) in the media, this paper presents the results of a study focused on the portrayal of women on the front pages of two of Croatia's national daily newspapers - Jutarnji list and Večernji list. The results show that men overwhelmingly dominate the fold, both as the subjects of texts and the subjects of photographs. Women, though rarely present, appeared more often than men as subjects in texts related to "lighter topics", e.g., entertainment. Both newspapers promoted stereotyped depictions of women such as their depiction only through the lens of motherhood, family and home, the division of "feminine" and "masculine" labor, women as the weaker sex, and an emphasis placed solely on their bodies.
\end{abstract}

\section{KEY WORDS}

PRESENCE AND IMAGE OF WOMEN, GENDER STEREOTYPES, NEWSPAPERS FRONT PAGES, CONTENT ANALYSIS

Authors note

Dunja Majstorović :: University of Zagreb, Faculty of Political Science, Zagreb, Croatia :: dunja.majstorovic@fpzg.hr

Gordana Vilović :: University of Zagreb, Faculty of Political Science, Zagreb, Croatia :: gordana.vilovic@fpzg.hr 


\section{INTRODUCTION}

There is perhaps no more important industry in promoting the image of women than mass media outlets, but the image of women, produced and reproduced in major daily newspapers, is rarely favourable. The many negative aspects in terms of how the media report on women were emphasized in the UN Report of the Fourth World Congress on Women, held in Beijing in 1995. The report included a warning about "the continued projection of negative and degrading images of women in the media" and asked for increase in "the participation and access of women to expression and decision-making in and through the media" (UN Report, 1995: 99-100). Similar conclusions were presented in the guidelines of the Parliamentary Assembly of the Council of Europe, adopted in April 2002. The Assembly concluded that women in the media are inadequately represented, and that their image is often stereotyped and sexist as they are either primarily associated with or seen solely through their private lives (household and family life), or often portrayed simply as sex objects (Parliamentary Assembly, 2002).

Nevertheless, and in spite of the constant warnings of media activists across various organisations (governmental and non-governmental), and the introduction of progressive legislation, the overall image and position of women in the media has not changed considerably. Getting the Balance Right: Gender Equality in Journalism, a report issued in 2009 by the International Federation of Journalists in collaboration with UNESCO, pointed out a number of concerning results from their study, most significantly the overall paltry presence of women in the media, ranging from $15 \%$ in the Middle East, to $26 \%$ in North America and the Pacific. In terms of topics featuring women, most fell within the prism of celebrities, arts, and sports ( $28 \%)$, whereas they were least present in the category of politics (14\%) (IFJ, 2009). In addition, the language in the media was full of bias against women. Further, the results of 2015 Global Media Monitoring Project (GMMP), the largest international study on the representation of women in the news, conducted every 5 five years beginning in 1995, demonstrated that women are rarely presented as the subjects of news- among all subjects in newspaper texts, $24 \%$ were women, while $76 \%$ were men. Despite the fact that women are more frequently featured in photographs $(30 \%)$, there is "evidence of [their] objectification and sexualisation", as they are "photographed in various stages of undress" as well as "in helpless, hopeless victim poses", in contrast to the far more common "profile shots of stoic, strong, authoritative male figures" (Macharia, 2015: 44).

These global studies have been confirmed by research conducted in individual countries, which it should be noted often differ in terms of the types of media present, as well as the subtopics related to women in the media (politicians, athletes...); however, the results are similar. Across the globe, women in the media are underrepresented, often portrayed in a sexualised and in subordinated way, and shown in stereotyped feminine roles (Collins, 2011). 


\section{THEORETICAL BACKGROUND AND RESEARCH}

This article begins with two characteristics of female representation in the media: the underrepresentation of women, and the stereotyped depiction. Underrepresentation is perhaps best described with the term "symbolic annihilation," first used by George Gerbner, which signifies how "representation in the fictional world signifies social existence; absence means symbolic annihilation" (Gerbner and Gross, 1979: 375). In 1978, the term was modified by Gaye Tuchman, who added condemnation and trivialisation to the equation, as a means to argue that out of the relatively few women in the media, those who are working are condemned, while the "others are trivialised, symbolised as child-like adornments who need to be protected or they are dismissed to the protective confines of the home" (Tuchman, 2000: 154). Margaret Gallagher explains further how the term itself has become "a powerful and widely used metaphor to describe the ways in which media images make women invisible," noting that,

[t] his mediated invisibility ... is not achieved simply through the non-representation of women's points of view or perspectives of the world. When women are 'visible' in the media content, the manner of their representation reflects the biases and assumptions of those who define the public - and therefore the media-agenda. (Gallagher, 2014: 23)

Eran Shor et al. cite numerous studies to show "that women's marginalisation in the media is due not only to their underrepresentation, but also to the stereotypic and often subordinating, belittling, and demeaning ways in which they are portrayed." (Shor et al., 2014: 768) Numerous studies support these findings in various types of media, from including both printed (Shor et al., 2014) and online newspapers (Mateos de Cabo et al., 2014), as well as analyses of photographs (Stanley, 2012; Len-Ríos et al., 2005; PriceRankin, 2001), and specialised studies of front pages (Potter, 1985). In addition, various studies have been conducted on more specific topics related to the representation and the image of women in newspapers such as, including the depiction of female offenders (Brennan and Vandenberg, 2009; Collins, 2014); coverage of male and female athletes (Godoy-Pressland, 2014; Weber and Carini, 2012) and how it pertains to the Olympic Games (Vincent et al., 2002; Crolley and Teso, 2007; King, 2007); and the depiction of female politicians (Ibroscheva and Raicheva-Stoverb, 2009; Garcia-Blanco and WahlJorgensen, 2012; O'Neill and Savigny, 2014), among others. Studies at the national level, and in particular two in Spain, reveal the more frequent presence of men not just in texts, but as well as in photographs and advertisements (Matud et al, 2011). On the other hand, these studies reveal that women are far more present in sections related to society and culture, or shorter news items, and in Sunday editions (Mateos de Cabo et al., 2014). Sen Jia et al. further confirm this trend in a large study whose results show that "the domains where women are more present include fashion and entertainment, while men are more associated with business and politics." (Jia et al., 2016: 8) Even though women were more present in images than in text, their conclusion is that the news media are still maledominated "with an overall probability of $77 \%$ that an entity mentioned in the text is male, or $69.6 \%$ that a face image is male." (Jia et al., 2016: 8) Longitudinal studies have also confirmed much of the above-noted results, including one analysis of more than a 
thousand photographs published in The New York Times and The New York Daily News from 1966 to 2006, which corroborated the overall dominance of men, despite the differences in the profiles of the two newspapers (Stanley, 2012). Another study of thirteen newspapers spanning 1880 to 2008 showed that women have been poorly represented all through modern history with only a modest uptake being registered in recent decades (Shor et al., 2014) while Karen Ross points out how the last 20 years "have seen scant improvement in the ways in which women are regularly represented in the media." (Ross, 2017: 31)

In Croatia there are relatively few analyses concerning women's representation in the media, among them only several were conducted in the last ten years. Irena Sever and Alen Andraković (2013), as well as Svjetana Knežević and Viktorija Car (2011), focused on the representation of women on television while Nirman Bamburać Mornjak, Tarik Jusić, and Adla Isanović (2006) conducted a large study that included nine daily newspapers in Bosnia and Herzegovina, Croatia, and Serbia. The results of their research have shown conclusively that men dominate nearly all media outlets and are associated with important and serious subjects, such as politics and economics, while women are more exclusively associated with entertainment, culture and art. In terms of social roles, men are more evenly distributed across different professions and occupations, in contrast to women, who are far more often displayed as either household figures, i.e., as mothers, or instead associated with the sex industry. (Bamburać Mornjak et al., 2006) Crime, entertainment and lifestyle were the most frequent sections female characters appeared in according to the analysis by Inga Tomić-Koludrović and Mirko Petrić (2004). They also found that "in the total of the verbal text, there were $81.1 \%$ of male characters and only $18.9 \%$ of female characters" as well as that "there are far more female characters in the visual than in the verbal texts" since there were $31 \%$ of visual appearances of female characters (Tomić-Koludrović and Petrić, 2004: 812-813). That men are far more often the subjects of photographs, and worse, that photographs of women put more emphasis on their physical and sexual characteristics was also concluded by the above-mentioned study by Bamburać Mornjak, Jusić, and Isanović, whose overall conclusion was that there were no significant differences among the analysed newspapers across three countries, since the "daily newspapers in Bosnia and Herzegovina, Croatia and Serbia construct a genderbiased and discriminatory discourse." (2006: 77)

Althoughthejournalism profession in Croatia "has gonethroughaprocess offeminisation with the majority of journalism students now being female" (Vozab and Zember, 2016: 79) this seems not to be reflective in the way the media report on women'. In accordance with these results, the overall purpose of this study is to ascertain whether Croatian daily newspapers, in terms of texts on front pages, continue to either underrepresent women, or overly stereotype more classic and historically fraught feminine roles.

\footnotetext{
${ }_{1}^{1}$ Even though majority of journalism students in Croatia are women, majority of employed journalists are still men. Out of all unemployed journalists, $65 \%$ are women, „, and the salaries of those who are employed are around 87 percent of those of men in comparable positions." (Vozab and Zember, 2016: 76)
} 


\section{METHODOLOGICAL FRAMEWORK}

The following research aims to answer four questions:

1) Is there a difference in the presence of women and men as text subjects (years and papers combined)?

2) Is there a difference in the presence of women and men as text subjects between the analysed newspapers ( $J L$ and VL; years combined) and between analysed years (2011 and 2014; papers combined)?

3) Is there a difference in the presence of women and men as text subjects according to thematic areas in which they appear (years and papers combined)?

4) What stereotypes, if any, persist when women are the subjects of texts and photographs?

Both quantitative and qualitative content analysis research methods were conducted by the authors. We selected all of the texts (and the accompanying photographs) whose titles appeared on the front pages of the Croatian daily newspapers Jutarnji list and Večernji list and analysed them in terms of: 1) determining the gender of the text subjects: women, men, no gender ${ }^{2}$, and joint appearance ${ }^{3} ; 2$ ) classification of texts with women and men as subjects according to the following thematic areas in which they appear: crime chronicle ${ }^{4}$; the European Union and foreign politics; the economy; crime ${ }^{5}$; entertainment ${ }^{6}$; sports; domestic politics; education ${ }^{7}$, science and health; other. ${ }^{8}$

As a means to determine whether or not women have been portrayed by traditional stereotypes, this study performed a qualitative content analysis of all the texts and the accompanying photographs where women were deemed the subjects. These texts were subsequently segmented into six categories concerning the presentation of women (and based on the frequency of examples): 1) the presentation of women solely in the function of motherhood, or rather, their role within the family and home; 2 ) the portrayal of women as the weaker sex; 3) women engaged in traditionally 'male' jobs; 4) women's professional life is not separated from her private life; 5) woman's appearance as the dominant factor (i.e., emphasis on her physical characteristics) and marriage as a woman's sole ambition; 6) the use of the female body to attract attention (category for photographs).

The content analysis was performed on 1,552 front page texts from the print editions of Jutarnji list (JL) and Večernji list ${ }^{9}(\mathrm{VL})$, published in two separate periods from March through May 2011 (335 texts in JL and 328 in VL); and from March through May 2014 (409 texts in $J \mathrm{~L}$ and 480 in VL). The use of two three month-periods several years apart (2011 and 2014) was purposefully chosen so as to include two different governments/two

\footnotetext{
2 'No gender' refers to texts with no human subjects, or texts with human subjects in general (including children).

3 Joint appearance refers to texts with both women and men as subjects (Table label W+M).

4 Category "crime chronicle" includes texts about: accidents and traffic accidents, smaller robberies, etc.

${ }^{5}$ Category "crime" includes tex ts about: war crimes, economy crimes and crime in general (robberies, drugs, prostitution, etc.)

6 Texts on celebrities: singers, actors, TV hosts, models, etc.

${ }^{7}$ All levels of education: elementary and secondary schools, college, etc.

${ }^{8}$ Category "other" includes texts about: culture, law, natural disasters.

9 Večernji list is translated as "The Evening Paper", while Jutarnji list is translated as "The Morning Paper".
} 
different political options, as well as two different prime ministers, one female in 2011, and one male in $2014 .^{10}$

Both Jutarnji list and Večernji list are characterised as semi-tabloids:;1 as defined by Dick Rooney (2000): both feature an attractive front page, utilise emotional language over objective language, present large headlines, and make extensive use of photographs, graphics and colours (Rooney, 2000: 91).

\section{RESEARCH RESULTS AND DISCUSSION}

The number of texts with women as the subject on the front pages of both analysed newspapers (Jutarnji list and Večernji list) and both analysed years (2011 and 2014) was 209 (13\% of all front page texts) while the number of texts with men as the subject was 852 ( $55 \%$ of all front page texts). As expected the difference in the number of female and male subjects in both newspapers is statistically relevant $(\chi 2=389.68, p=.000)^{12}$ Such results correspond to various studies mentioned in theoretical background of the paper (e.g. Shor et al., 2014, Matud et al., 2011, Bamburać Mornjak et al., 2006) and clearly demonstrate the marginalisation of women on the front pages of the selected Croatia's daily newspapers.

Out of 1,281 photographs, in total there were 225 portraying women (17.5\% of all front page photographs) while the number of male subjects in photographs was 843 (66 $\%$ of all front page photographs).

\section{Text and photograph subjects by analyzed newspapers and years}

The content analysis of the front page texts of Jutarnji list established that men were the sole subjects in $48 \%$ of texts in 2011, and in $60 \%$ of texts in 2014 . In contrast, women were the sole subjects in only $16 \%$ of texts in 2011, and a paltry $12 \%$ in 2014.

In Večernji list, the research determined that men were the sole subjects of $60 \%$ of front page texts in 2011, and in $52 \%$ in 2014. Likewise, women were the sole subjects in 14 $\%$ of texts in 2011, and $12 \%$ in 2014. (Table 1)

The results also show that the differences in the representation of genders in the analysed years (2011 and 2014) $(x 2=3.37, p=.066)$, or by newspapers ( $\mathrm{L}$ and $\mathrm{VL})(x 2=0.13$,

\footnotetext{
$\overline{{ }^{10} \text { In } 2011}$ the ruling political party was the Hrvatska demokratska zajednica (the Croatian Democratic Union) and the prime minister was Jadranka Kosor (in office from 1 July 2009 to 23 December 2011). In 2014 the government was a coalition of the left-wing political parties led by the Socijaldemokratska partija Hrvatske (the Social Democratic Party) and the prime minister was Zoran Milanović (in office from 23 December 2011 to 22 January 2016). A list of all governments is available online (Vlada RH, 2017).

11 The tabloidisation of newspapers as defined by Frank Esser (1999: 293) in Croatia took place in the early 1990s along with the democratic changes, privatisation and the entry of foreign capital in the media (Vilović, 2004). Characteristics of tabloidisation such as, relevant news presented in a lighter way, more illustrations and photographs, shorter texts of marginal social value, but attractive to the widest audience, extremely long titles (up to thirty words) containing all the relevant information in the texts, lack of journalism ethics, etc. (Vilović, 2003) became visible at that time but continued to flourish in the past 25 years thus resulting in the lack of serious newspapers in the media market.

12 In the analysis of differences in the study, a significance level of $5 \%(p<0.05)$ was used and the p-value was calculated for each test.
} 
$p=.718$ ) are not statistically relevant so the derived conclusion is of no differences between the analysed newspapers or analysed years in terms of the presence of women as subjects. In both newspapers, in both analysed time periods, women are barely visible in texts on front pages (Table in the appendix).

Table 1. Subjects of texts by gender in the analysed newspapers (Jutarnji list and Večernji list) and by the analysed years (2011 and 2014)

\begin{tabular}{lllllll} 
Newspaper & Analyzed year & \multicolumn{4}{c}{ Text subjects by gender } & Total number of texts \\
\cline { 3 - 6 } Jutarnji list & & M & W & M+W & No gender & \\
& 2011 & $48 \%$ & $16 \%$ & $13 \%$ & $23 \%$ & 335 \\
& 2014 & $60 \%$ & $12 \%$ & $10 \%$ & $18 \%$ & 409 \\
\hline \multirow{2}{*}{ Večernji list } & 2011 & $60 \%$ & $14 \%$ & $8 \%$ & $18 \%$ & 328 \\
& 2014 & $52 \%$ & $12 \%$ & $13 \%$ & $23 \%$ & 480 \\
\hline
\end{tabular}

The number of photographs portraying women was higher than the number of texts - in Jutarnji list 23 \% in 2011 and 14 \% in 2014; in Večernji list 16 \% in 2011 and $18 \%$ in 2014. Nevertheless, men dominated front page photographs. In 2011, they were the subjects of $54 \%$ of all photographs in Jutarnji list and $70 \%$ in Večernji list; in 2014, $73 \%$ of photographs had male subjects in Jutarnji list and $65 \%$ in Večernji list.

\section{Analysis of text subjects according to thematic categories}

In terms of thematic categories in both analysed newspapers and time periods, women were most commonly the subjects of texts as follows: entertainment (52 texts), domestic politics (37 texts) and crime (33 texts). It is important to mention that the relatively high number of women as the primary subject of domestic politics in texts in 2011 is certainly due to the fact that the prime minister was a woman (Jadranka Kosor), while in 2014, there were several prominent female ministers in the Government, including the deputy prime minister and later minister of foreign affairs (Vesna Pusić). Regarding the relatively high number of women as the primary subject in crime-related stories in 2014, and for men in 2011, it is relevant to mention the charges brought against former Deputy Minister of Tourism Vinka Cetinski, and former Prime Minister Ivo Sanader, both of which were major media stories.

Men were most frequently the subjects of texts in the following categories: domestic politics (178 texts), crime (158 texts) and sports (134 texts). (Table 2 ) In 2014, the high number of male subjects in sports stories was in fact due to the Croatian men's national football team's upcoming performance in the World Cup in Brazil, a topic covered extensively in the months leading up to the first matches in June 2014.

From this data, it is apparent that women are more often the primary subjects in texts considered to be "less serious", a fact which is particularly evident in the data from 2011 since both newspapers most frequently featured women as the subjects in entertainment- 
related texts. The differences between the presence of women and men as subjects are statistically significant $(x 2=154.12, p=.000$ ) (Table in the appendix) and are again consistent with other studies, for instance by Tomić-Koludrović and Petrić (2004); Bamburać Mornjak et al., (2006) and Jia et al. (2016).

Table 2. Women and men as subjects in texts according to thematic categories in which texts appear in both analysed newspapers (Jutarnji list and Večernji list) and analysed years (2011 and 2014)

\begin{tabular}{llllllllllll} 
Thematic categories & \multicolumn{4}{l}{ Text subjects in JL } & \multicolumn{3}{c}{ Text subjects in VL } & \multicolumn{2}{c}{ Total (JL + VL, } \\
in which texts appear & 2011 & & 2014 & & 2011 & & 2014 & & $2011+2014)$ \\
& W & M & W & M & W & M & W & M & W & M \\
Domestic Politics & 12 & 36 & 7 & 40 & 8 & 24 & 10 & 78 & 37 & 178 \\
Crime & 4 & 39 & 15 & 36 & 5 & 62 & 9 & 21 & 33 & 158 \\
Sports & 1 & 17 & 0 & 47 & 0 & 36 & 2 & 34 & 3 & 134 \\
Economy & 1 & 7 & 2 & 27 & 2 & 18 & 6 & 39 & 11 & 91 \\
Other & 10 & 15 & 6 & 32 & 6 & 3 & 8 & 20 & 30 & 70 \\
Eu And Foreign Politics & 1 & 18 & 2 & 19 & 1 & 16 & 8 & 19 & 12 & 72 \\
Entertainment & 22 & 8 & 11 & 10 & 14 & 8 & 5 & 5 & 52 & 31 \\
Crime Chronicle & 1 & 10 & 6 & 14 & 10 & 13 & 1 & 2 & 18 & 39 \\
Education, Health And Science & 2 & 2 & 0 & 16 & 2 & 4 & 9 & 17 & 13 & 39 \\
Church & 0 & 10 & 0 & 5 & 0 & 12 & 0 & 13 & 0 & 40 \\
Total & 54 & 162 & 49 & 246 & 48 & 196 & 58 & 248 & 209 & 852 \\
\hline
\end{tabular}

\section{Stereotyped texts and photographs portraying women}

A qualitative content analysis was performed on both texts and photographs as a means to analyse any and all stereotypical portrayals of women. The texts found to contain such depictions were later categorised (as noted above in the research methodology).

In total, there were 30 texts containing stereotypes found in both newspapers in both analysed time periods (JL: 7 in 2011 and 6 in 2014; VL: 6 in 2011 and 11 in 2014) which marks $14 \%$ of all texts with women as subjects and 23 stereotyped photographs (JL: 4 in 2011 and 9 in 2014; VL: 4 in 2011 and 6 in 2014) or 10\% of all photographs with women. Regarding the differences in stereotyped portrayals of women between the analysed newspapers, the research finds that the differences in the results are not statistically significant $(\chi 2=0.50, p=.481)$, as well as the differences between the analysed years $(\chi 2=0.42, p=.517)$. In terms of the photographs, there are again no statistically significant differences in the stereotypical portrayal of women between the analysed newspapers ( $x^{2}=0.60, p=.440$ ), nor between the analysed years $(x 2=0.97, p=.325)$ (Table in the appendix). These results serve as a further demonstration that there are no statistically significant differences between Jutarnji list and Večernji list in all the analysed categories (subject gender, thematic categories of texts the subjects appear in, and stereotypical depiction). Since there were no statistically relevant differences between the analysed years as well, the 
results show no change in the period of three years regarding the presence and portrayal of women on the newspapers' front pages.

Overall, the discovery of a varied and considerable amount of stereotyped portrayals of women on the front pages of both Jutarnji list and Večernji list is cause for alarm, particularly given that only one such article is enough to propagate certain perceptions of women.

The presence of gender stereotypes in Croatia can be explained by the fact that the discrimination of women is deeply rooted in the country's patriarchal culture (Barada et al., 2004: 9-10). When they first emerged in Croatia in the 1990s, studies conducted on the national level (Vozab and Zember, 2016: 74) demonstrated how the "media were active together with dominant cultural politics of retraditionalisation in shaping and promoting traditional gender roles and stereotypes." (Kunac and Sarnavka, 2006: 18 cf. Vozab and Zember, 2016: 74). For Tomić-Koludrović and Petrić the specificity of Croatian society in the 1990s was the "reemergence of traditional patriarchal structures" that resulted in a "dramatic increase of national and gender stereotypes in the public discourse." (2004: 804) The data we obtained through the research suggests that this gender biased discourse continues to date.

As a part of our study's qualitative content analysis, stereotypical texts were grouped into several categories corresponding to some of the common and preexisting stereotypes about women and male-female relations. In accordance with the established categories, some representative texts from both newspapers were selected and analysed.

\section{THE PRESENTATION OF WOMEN SOLELY IN THE FUNCTION OF MOTHERHOOD, THEIR FAMILY AND HOME}

This category mainly referred to successful (business) women who were portrayed as selfish careerists, who chose to subordinate family life to either work or their lifestyle choices, and were subject to a wide-array of criticism. One representative example referred to female television presenters where, in the mere headline, it was possible to detect a prejudicial tone regarding their lifestyle choice - "Lonely and beautiful: Without family and children, their private life is a hobby, and their work their life" (JL, 9 March 2011). Since women are still "expected to perform duties as wife and mother, in addition to fulfilling their professional responsibilities" (Domenico and Jones, 2006: 1) when women choose a career that is as challenging as professional politics, this is often regarded as incompatible with family life. In the text entitled "Two politicians, two careers" (JL, 31 March 2011) this notion is underlined since two choices made by two female Croatian politicians were deemed as "different and inconsistent careers" - Kolinda Grabar Kitarović became the new Assistant of NATO Secretary General, and Bianca Matković became a mother. Again, in terms of women's family duties, one text questioned the responsibility and morality of mothers who participate in the reality show Big Brother - in the same tone present in the headline, much like the first example - "New Big Brother: Mom is in the BB house, a child in front of the TV? Negligence..." (VL, 15 March 2011). 


\section{PORTRAYAL OF WOMEN AS THE WEAKER SEX}

One analysed text used the outdated classification of women as the weaker sex. The text entitled "State saves on the weak: children, the disabled and women remain unprotected" (JL, 24 April 2011) warns of the possible abolition of the Ombudsman for Children, Gender Equality, and the Disabled, respectively (or the potential merger of these three institutions within the Office of the Ombudsman), but suggests that women, as two others frequently discriminated and unprotected groups (children and the disabled) can be characterised as "weak".

\section{WOMEN ENGAGED IN TRADITIONALLY “MALE” JOBS}

The division of professions into "male" and "female" is visible in several of the analysed texts. The text entitled "Croatian premier: For the first time the head of the state is being guarded by a woman. And she is dangerous" (JL, 7 May 2011) underlines that this division remains particularly orthodox in some professions like bodyguards. It too is consistent with the image of for instance female police officers who are still "confronted with the 'traditional view that women do not belong on patrol because of their lack of physical strength and ability to maintain an authoritarian presence in the face of challenges that the public can present to police" (Grennan, 1987 cf. Ffrench and Waugh, 1998: 260). This again is visible in another text "Vjekoslava Goričanec from Zadar: I am a single mother who earns by clearing fields of landmines" (VL, 27 March 2011) that too serves as an example of how a woman's private life is not separated from her work even though the text's focus was the work itself. Another analysed text "Croatia's 11 most accomplished female chefs" (VL, 13 April 2014) referrers to women chefs that have "managed to win the (male) world of cuisine" and how they have succeeded despite their femininity, thanks to some "masculine" characteristics.

\section{A WOMAN'S PROFESSIONAL LIFE IS NOT SEPARATED FROM HER PRIVATE LIFE}

This category is not strictly a stereotype but rather a way in which the analysed newspapers have reported on successful women. Even though the main motives for the texts themselves was the accomplishment of women in terms of their work/career, as indicated in each headline, the main focus of the texts in fact was their private life. In the text "Women in Science: Four young winners of UNESCO scholarship" (VL, 5 March 2014) the entire first paragraph was solely about the private lives of young and successful Croatian scientists:

Four young women - four scientists. Two from Zagreb, one from Slavonski Brod, the fourth is from Stari Grad; three are married. One has two sons, and is currently on maternity leave, the other says that she must carefully plan having children since there is a two-year specialisation abroad awaiting her and her husband... The third one told us that she was in a stable relationship, but that there was still enough time for children, and the fourth delighted us with the news that at the time she learned about winning her scholarship, she also discovered that she was pregnant. Her twins arrive in the fall. 
The same tone was noticed in the text "Among the 40 best biologists worldwide / Iva Tolić: I hope to decipher the secret of ageing" (VL, 18 May 2014) where a piece of text devoted to a scientist's family life is put in the same sentence with work responsibilities and achievements: "Between the obligations she still has at the Max Planck Institute and the Institute Ruđer Bošković, thirty-nine-year-old Iva Tolić is preparing her wedding and looking forward to the arrival of her first child, a son." In addition, the analysed text often referenced her appearance and looks, which again only reduces the space dedicated to career or personal accomplishments: "Paris blue dress, shoes, bag and coat full of flowers, loose hair and pregnant belly revealed a content woman who, after fifteen years of living in four different countries and two continents, came home." (VL, 18 May 2014). This is consistent with the conclusions of the Annual Report on the Women in Croatia by the Ombudsperson for gender equality about the large number of media that still use the

female body as an object to attract attention of readers or viewers to other media content or for the purpose of evaluating women primarily on the basis of their looks, regardless of whether they are models, celebrities, politicians, scientists or the President of Croatia. (Ombudsperson for Gender Equality, 2017: 22)

One of the analysed texts entitled "Oncologist Ljerka Eljuga: the hardest part is when I have to tell a girl before her wedding that she has cancer" (VL, 19 March 2014) serves not only as the example of how a woman's professional life is not separated from her private life, but also as the mentioned reference of the expectation that women should, apart from fulfilling their professional responsibilities, perform duties as wives and mothers (Domenico and Jones, 2006: 1). In that terms, the doctor in the analysed text is described as a "superwoman," who somehow managed to achieve and maintain both a career and motherhood: "... a doctor, a mother of four, was one of the best students in her class who managed, with all four pregnancies and the status of a young wife of a traditional and temperamental southerner, to graduate on time." (VL, 19 March 2014)

\section{WOMAN'S APPEARANCE AS THE DOMINANT FACTOR / MARRIAGE AS AN ONLY WOMAN'S AMBITION}

The qualitative analysis shows that women "still remain in stereotypical media roles which perceive women as objects to be looked at" (Vozab and Zember, 2016: 78). For instance, a text "Kolinda shone in the USA: Ambassador's appearance overshadowed young Miss contenders" (VL, 30 March 2011) demonstrates how a woman's appearance is crucial, even when she obtains a particularly noteworthy public office, like the Ambassador to the United States. References to a politician's appearance, particularly female politicians, is a common phenomenon in the Croatian media, but moreover, it is noteworthy that the Ambassador is addressed only by her first name, a far less frequent phenomenon for her male colleagues, and a fact which continued even after she became the President of Croatia (her current function). The perception of women as objects is visible in another example -the text entitled "Daniela: I weigh 7.5 kilograms less and 100,000 kuna more: Two months-ago it all seemed hopeless, now I'm getting married and I'm going to Italy" (JL, 19 April 2011) suggests this woman's moving abroad and marriage is directly associated with her new and more attractive physical appearance. 


\section{THE USE OF A WOMAN'S BODY TO ATTRACT ATTENTION (PHOTOGRAPHS)}

Using an attractive female body in order to obtain attention from the reader was especially visible on photographs in the analysed newspapers. In a study about gender stereotypes of female and male artists in Taiwanese tabloids, Hung-Chung Wang concluded how the analysis "demonstrated that at least seven entries conveyed a stereotypical preconception of female celebrities using physical attractiveness to put themselves in the spotlight" (Wang, 2009: 757). This was visible is one of our sample in texts "Naked Nika Fleiss" (JL, 7 April 2011) about the Croatian skier who reached the front page of the newspaper because she had posed for Playboy.

Other examples used naked or barely dressed women in photographs accompanying texts whose content did not justify the use of such photographs - the text "A scandal in a super museum" (JL, 21 April 2011) about the decay of art in the Museum of Contemporary Art was accompanied by a photograph of a naked female statue; the text "Scarves and shirts for naked tourists" (VL, 26 May 2011), which referred to a new dress code when entering a church in Vodnjan was accompanied by a large and totally inadequate photograph of a model at a fashion show wearing only underwear.

\section{CONCLUSION}

In this study we analysed a total of 1,552 texts on the front pages of two Croatian national daily newspapers, Jutarnji list (740 texts) and Večernji list (812 texts) over the course of two three-month periods, March to May 2011, and March to May 2014. Each front page text was analysed by the subject's gender, and later grouped into different thematic categories. A separate analysis of both texts and photographs was performed in order to ascertain whether women were predominantly described through the lens of various stereotypical norms.

In terms of results, men are the primary subjects on the front pages of Croatian dailies. They were the subjects of $55 \%$ of all published texts in both newspapers in both time periods. Correspondingly, women were featured far less often and accounted for only $13 \%$ of all published texts. Similarly, women were underrepresented on photographs as well - they were the subjects of $17.5 \%$ of all published photographs, while $66 \%$ of all published photographs had male subjects. Further, when women were the primary subjects of texts and photographs, it was much more likely that the text centred on a "less serious" thematic areas, e.g., entertainment. Of particular concern, women were also very likely to be given a stereotypical portrayal. More specifically, it was found that $13 \%$ of texts and $12 \%$ of photographs in Jutarnji list and $16 \%$ of texts and $9 \%$ of photographs in Večernji list showed women stereotypically. 
Stereotypical texts tend to show women exclusively as mothers, through the prism of their family and home life; in them they are regarded as the "weaker" sex; their physical attributes and appearances are given significant attention; and they too often attain headlines only when found to be doing work outside of the pre-programmed norms of what constitutes male and female jobs. Photographs too often show women in "various stages of undress" (Macharia, 2015: 44), thus contributing to their objectification and the idea that they are desirable only when they are young and beautiful.

The overall findings of the research regarding the presence of women on the front pages of Croatia's daily newspapers are consistent with studies at the international level that show the marginalisation of women in newspaper (both online and traditional) texts (Jia et al., 2016; Shor et al., 2017; Stanley, 2012; Matud et al., 2011). Regarding their portrayal, the stereotypical depiction of women found in the analysed texts in numbers that cannot be neglected show how that "re-traditionalisation and the retrograde domestification of women, which took place in the 1990s [in Croatia], seem to have continued into the 2000s and now the 2010s, mixing with the media's commercial logic." (Vozab and Zember, 2016: 80).

This study took specific aim at the representation (presence and portrayal) of women on the front pages of newspapers. They are the most important features of newspapers since they are primarily intended to sell the rest of the paper to the buying public. Since journalists and foremost editors make great efforts to create attractive headlines and accompanying photographs, one could argue that there could be differences in the presence (and maybe sporadically in the portrayal) of women inside the newspapers, and not just in the texts with headlines announced on the front page. Therefore, these results should call for another, more comprehensive study that would include a content analysis of all the content within a set of newspapers.

\section{References}

>Bamburać Mornjak, Nirman; Jusić, Tarik and Isanović, Adla (2006) Stereotyping: Representation of Women in Print Media in South East Europe. Sarajevo: Mediacentar Sarajevo.

>Barada, Valerija; Borić, Rada; Jelavić, Željka; Mamula, Maja and Sarnavka, Sanja (2004) Uostalom, diskriminaciju treba dokinuti! Priručnik za analizu rodnih stereotipa. Zagreb: Centar za ženske studije. >Brennan, Pauline K. and Vandenberg, Abby L. (2009) Depictions of Female Offenders in FrontPage Newspaper Stories: The Importance of Race/Ethnicity. International Journal of Social Inquiry 2 (2): 141-175.

>Collins, Rachael E. (2014) 'Beauty and Bullets': A Content Analysis of Female Offenders and Victims in Four Canadian Newspapers. Journal of Sociology 52 (2): 296-310. DOI: 10.1177/1440783314528594. >Collins, Rebecca L. (2011) Content Analysis of Gender Roles in Media: Where are we Now and Where Should We Go? Sex Roles 64 (3): 290-298. DOI:10.1007/s11199-010-9929-5.

$>$ Crolley, Liz and Teso, Elena (2007) Gendered Narratives in Spain: The Representation of Female Athletes in Marca and El País. International Review for the Sociology of Sport 42 (2): 149-166. DOI: $10.1177 / 1012690207084749$.

>Domenico, Desirae M. and Jones, Karen H. (2006) Career Aspirations of Women in the 20th Century. Journal of Career and Technical Education 22 (2): 1-7. DOI: 10.21061/jcte.v22i2.430. 
>Esser, Frank (1999) Tabloidization of News: A Comparative Analysis of Anglo-American and German Press Journalism. European Journal of Communication 14 (3): 291-324. DOI: 10.1177/0267323199014003001.

$>$ Ffrench, Margot and Waugh, Linda (1998) The Weaker Sex? Women and Police Work? International Journal of Police Science \& Management 1 (3): 260-275. DOI: 10.1177/146135579800100305.

$>$ Gallagher, Margaret (2014) Media and the Representation of Gender, pp. 23-32 in Carter, Cynthia; Steiner, Linda and McLaughlin, Lisa (eds) The Routledge Companion to Media \& Gender. London and New York: Routledge, Taylor \& Francis Group. DOI: 10.4324/9780203066911.ch1.

$>$ Garcia-Blanco, Iñaki and Wahl-Jorgensen, Karin (2012) The Discursive Construction of Women Politicians in the European Press. Feminist Media Studies 12 (3): 422-441. DOI: 10.1080/14680777.2011.615636.

$>$ Gerbner, George and Gross, Larry (1979) Living with Television: The Violence Profile, pp. 363-393 in Newcomb, Horace (ed.) Television: The Critical View. ( $2^{\text {nd }}$ edition). New York: Oxford University Press. http://web.mit.edu/211.432/www/readings/Gerbner_Gross_LivingWithTelevision_ViolenceProfile. $\operatorname{pdf}(28.08 .2016)$.

$>$ Godoy-Pressland, Amy (2014) 'Nothing to Report': a Semi-Longitudinal Investigation of the Print Media Coverage of Sportswomen in British Sunday Newspapers. Media, Culture \& Society 36 (5): 595609. DOI: $10.1177 / 0163443714532977$.

>lbroscheva, Elza and Raicheva-Stover, Maria (2009) Engendering Transition: Portrayals of Female Politicians in the Bulgarian Press. Howard Journal of Communications 20 (2): 111-128. DOI: $10.1080 / 10646170902869429$.

>IFJ (2009) Getting the balance right: Gender equality in journalism. Brussels: International Federation of Journalists.

$>$ Jia, Sen; Lansdall-Welfare, Thomas; Sudhahar, Saatviga; Carter, Cynthia and Cristianini, Nello (2016) Women are Seen More than Heard in Online Newspapers. PLoS ONE 11 (2): 1-11. DOI: 10.1371/ journal.pone.0148434.

>King, Cristopher (2007) Media Portrayals of Male and Female Athletes: A Text and Picture Analysis of British National Newspaper Coverage of the Olympic Games since 1948. International Review for the Sociology of Sport 42 (2): 187-199. DOI: 10.1177/1012690207084751.

>Knežević, Svjetlana and Car, Viktorija (2011) Žene u televizijskim vijestima - analiza središnjih informativnih emisija HTV-a, RTL-a i Nove TV. Medijske studije 2 (3-4): 76-93.Len-Ríos, María; Rodgers, Shelly; Thorson, Esther and Yoon, Doyle (2005) Representation of Women in News and Photos: Comparing Content to Perceptions. Journal of Communication 55 (1): 152-168. DOI: 10.1111/j.14602466.2005.tb02664.x.

>Macharia, Sarah (2015) Who Makes the News?: Global Media Monitoring Project 2015. World Association for Christian Communication. http://whomakesthenews.org/gmmp/gmmp-2015reports (30.06.2016).

> Mateos de Cabo, Ruth; Gimeno, Ricardo; Martínez, Miryam and López, Luis (2014) Perpetuating Gender Inequality via the Internet? An Analysis of Women's Presence in Spanish Online Newspapers. Sex Roles 70 (1-2): 57-71. DOI: 10.1007/s11199-013-0331-y. >Matud, M. Pilar; Rodríguez, Carmen and Espinosa, Inmaculada (2011) Gender in Spanish Daily Newspapers. Sex Roles 64 (3-4): 253-264. DOI: 10.1007/s11199-010-9874-3.

$>$ McCombs, Maxwell E. and Shaw, Donald L. (1972) The Agenda-Setting Function of the Mass Media. The Public Opinion Quarterly 36 (2): 176-187. DOI: 10.1086/267990.

>Ombudsperson for Gender Equality (2017) Annual Report 2016. http://www.prs.hr/attachments/ article/2264/ANNUAL\%20REPORT\%20SUMMARY\%202016_FINAL_8_9_2017.pdf (15.09.2017). $>O^{\prime}$ Neill, Deirdre and Savigny, Heather (2014) Female Politicians in the British Press: The Exception to the 'Masculine' Norm? Journalism Education 3 (1): 6-27.

>Parliamentary Assembly (2002) Recommendation 1555. The Image of Women in the Media. http:// www.globalmediapolicy.net/sites/default/files/Recommendation\%201555\%20-\%20The $\% 20$ image\%20of\%20Women\%20in\%20the\%20media.pdf (09.09.2015). 
>Potter, W. James (1985) Gender Representation in Elite Newspapers. Journalism Quarterly 62 (3): 636-640. DOI: 10.1177/107769908506200327.

>Price-Rankin, Kelly Blake (2001) Male Visual Dominance Continues: a Global Study of Images of Men and Women in 750 Online Newspapers in 74 Nations. Master's Thesis. Electronic Thesis and Dissertations. Paper 51. http://dc.etsu.edu/etd/51/ (22.09.2015).

$>$ Rooney, Dick (2000) Thirty Years of Competition in the British Tabloid Press: The Mirror and The Sun 1968-1998, pp. 91-110 in Sparks, Colin and Tulloch, John (eds) Tabloid Tales: Global Debates over Media Standards. Lanham: Rowman \& Littlefield.

>Ross, Karen (2017) Gender, Politics, News: A Game of Three Sides. Chichester: Wiley Blackwell. DOI: $10.1002 / 9781118561652$.

>Sever, Irena and Andraković, Alen (2013) Žena na javnoj televiziji: Slučaj informativnih emisija In medias res i Otvoreno. Nova prisutnost 11 (1): 5-21.

>Shor, Eran; van de Rijt, Arnout; Ward, Charles; Blank-Gomel, Aharon and Skiena, Steven (2014) Time Trends in Printed News Coverage of Female Subjects, 1880-2008. Journalism Studies 15 (6): 759-773. DOI: 10.1080/1461670X.2013.834149.

>Stanley, Jason (2012) Women's Absence from News Photos: The Role of Tabloid Strategies at Elite and Non-Elite Newspapers. Media, Culture \& Society 34 (8): 979-998. DOI: 10.1177/0163443712455559. Tomić-Koludrović, Inga and Petrić, Mirko (2004) Identities on the Net: Gender and National Stereotypes on Croatian Broad-Reach Portals. Društvena istraživanja 13 (4-5): 803-823.

>Tuchman, Gaye (2000) The Symbolic Annihilation of Women in the Mass Media, pp. 150-175 in Cronthers, Lane and Lockhart, Charles (eds) Culture and Politics: A Reader. New York: St. Martin's Press. DOI: 10.1007/978-1-349-62965-7_9.

$>$ UN (1996) United Nations Report on the Fourth World Conference on Women. Beijing, 4-15 September 1995. New York: United Nations. http://www.un.org/womenwatch/daw/beijing/pdf/Beijing\%20 full\%20report\%20E.pdf (09.09.2015).

>Vilović, Gordana (2004) Etički prijepori u Globusu i Nacionalu 1999.-2000. Zagreb: Fakultet političkih znanosti.

>Vilović, Gordana (2003) Istraživačko novinarstvo, tabloidizacija i etika. Društvena istraživanja. 12 (6): 957-974.

>Vincent, John; Imwold, Charles; Masemann, Vandra and Johnson, James T. (2002) A Comparison of Selected 'Serious' and 'Popular' British, Canadian, and United States Newspaper Coverage of Female and Male Athletes Competing in the Centennial Olympic Games: Did Female Athletes Receive Equitable Coverage in the 'Games of the Women'? International Review for the Sociology of Sport 37 (3): 319-335. DOI: 10.1177/101269020203700312.

$>$ Vlada RH (2017) Prethodne vlade. https://vlada.gov.hr/prethodne-vlade-11348/11348 (08.12.2017.). $>$ Vozab, Dina and Zember, Adela (2016) Croatia: Does Equality in Organization Lead to Equality in Content?, pp. 72-82 in Ross, Karen and Padovani, Claudia (eds) Gender Equality and the Media: A Challenge for Europe. New York and London: Routledge.

$>$ Wang, Hung-Chung (2009) Language and Ideology: Gender Stereotypes of Female and Male Artists in Taiwanese Tabloids. Discourse \& Society 20 (6):747-774. DOI: 10.1177/0957926509342379. $>$ Weber, Jonetta D. and Carini, Robert M. (2012) Where are the Female Athletes in Sports Illustrated? A Content Analysis of Covers (2000-2011). International Review for the Sociology of Sport 48 (2): 196203. DOI: $10.1177 / 1012690211434230$. 


\section{Appendix}

$>$ An overview of the main conclusions of the research with calculated significant differences for tested variables

\begin{tabular}{|c|c|c|c|}
\hline Tested $\mathbf{v}$ & $x^{2}$ & $p$ value test & Decision \\
\hline $\begin{array}{l}\text { Men and women in the texts on the front pages } \\
\text { of } J L \text { and VL. }\end{array}$ & 389,68 & 0 & $\begin{array}{l}\text { There is a significant } \\
\text { difference }\end{array}$ \\
\hline $\begin{array}{l}\text { Differences in the presence of men and women } \\
\text { subjects in the analyzed years ( } 2011 \text { and 2014). }\end{array}$ & 3,37 & 0,066 & $\begin{array}{l}\text { There is no significant } \\
\text { difference }\end{array}$ \\
\hline $\begin{array}{l}\text { Differences in the presence of men and women } \\
\text { subjects in the analyzed newspapers ( } J \mathrm{~L} \text { and VL). }\end{array}$ & 0,13 & 0,718 & $\begin{array}{l}\text { There is no significant } \\
\text { difference }\end{array}$ \\
\hline $\begin{array}{l}\text { Differences in presence of women and men } \\
\text { subjects by thematic areas in which they appear. }\end{array}$ & 154,12 & 0 & $\begin{array}{l}\text { There is a significant } \\
\text { difference }\end{array}$ \\
\hline $\begin{array}{l}\text { Stereotyped representation of women in texts } \\
\text { according to analyzed newspapers ( } \mathrm{L} \text { and } \mathrm{VL} \text { ). }\end{array}$ & 0,5 & 0,481 & $\begin{array}{l}\text { There is no significant } \\
\text { difference }\end{array}$ \\
\hline $\begin{array}{l}\text { Stereotyped representation of women in texts } \\
\text { according to analyzed years ( } 2011 \text { and 2014). }\end{array}$ & 0,42 & 0,517 & $\begin{array}{l}\text { There is no significant } \\
\text { difference }\end{array}$ \\
\hline $\begin{array}{l}\text { Stereotyped representation of women in } \\
\text { photographs according to analyzed newspapers } \\
(\mathrm{JL} \text { and } \mathrm{VL}) \text {. }\end{array}$ & 0,6 & 0,44 & $\begin{array}{l}\text { There is no significant } \\
\text { difference }\end{array}$ \\
\hline $\begin{array}{l}\text { Stereotyped representation of women in } \\
\text { photographs according to analyzed years } \\
\text { (2011 and 2014). }\end{array}$ & 0,97 & 0,325 & $\begin{array}{l}\text { There is no significant } \\
\text { difference }\end{array}$ \\
\hline
\end{tabular}

Note: $x^{2}$ - chi-square; $p<0.05$ 


\section{ZASTUPLJENOST I NAČIN PRIKAZIVANJA ŽENA NA NASLOVNICAMA HRVATSKIH DNEVNIH NOVINA: U SLUŽBI PROMICANJA RODNIH STEREOTIPA?}

\section{Dunja Majstorović :: Gordana Vilović}

SAŽETAK Osim što sudjeluju u oblikovanju javnoga mnijenja, ne smije se zanemariti da su mediji i alat za promicanje ili brisanje predrasuda i stereotipa. U tom kontekstu ovaj rad prikazuje rezultate istraživanja reprezentacije (zastupljenosti i načina prikazivanja) žena na naslovnicama hrvatskih dnevnih novina - Jutarnjeg lista $i$ Večernjeg lista. Rezultati pokazuju da muškarci dominiraju kao subjekti tekstova i fotografija. lako su rijetko prisutne, žene se češće od muškaraca pojavljuju kao subjekti u tekstovima koji se mogu okarakterizirati kao "laganije teme“, poput zabave. Uz to, navedene dvoje novine promiču stereotipno prikazivanje žena, što je vidljivo u prikazivanju žena isključivo kroz prizmu majčinstva, obitelji i doma, ali i podjele poslova na „ženske" $i$ „muške", u doživljavanju žena kao pripadnica slabijeg spola te u stavljanju naglaska isključivo na njihova tijela.

KLJUČNE RIJEČI

ZASTUPLJENOST I NAČIN PRIKAZIVANJA ŽENA, RODNI STEREOTIPI, NASLOVNICE, ANALIZA SADRŽAJA

Bilješka o autoricama

Dunja Majstorović :: Sveučilište u Zagrebu, Fakultet političkih znanosti, Zagreb :: dunja.majstorovic@fpzg.hr

Gordana Vilović :: Sveučilište u Zagrebu, Fakultet političkih znanosti, Zagreb :: gordana.vilovic@fpzg.hr 